\title{
Determinants of airport train operational performance
}

\author{
Prasadja Ricardianto ${ }^{\text {, Heriyanto Wibowo }}{ }^{a}$, Lira Agusinta ${ }^{a}$, Edi Abdurachman ${ }^{\text {a }}$, Abdullah Ade \\ Suryobuwono $^{\text {a }}$, Peppy Fachrial ${ }^{\mathrm{a}}$, Agus Setiawan ${ }^{\mathrm{a}}$, Salahudin Rafi ${ }^{\mathrm{a}}$, Siti Maemunah ${ }^{\mathrm{a}}$ and Endri \\ Endri $^{*}$
}

${ }^{a}$ Trisakti Institute of Transportation and Logistics, Jakarta, Indonesia

${ }^{b}$ Universitas Mercu Buana, Jakarta, Indonesia

\section{H R O N I C L E}

Article history:

Received: June 18, 202

Received in revised format: July

29,2021

Accepted: September 29, 2021

Available online: September 29 2021

Keywords:

Passenger Satisfaction

Airport Train Operational Perfor-

mance

Service Quality

Passenger Loyalty

\section{A B S T R A C T}

This study aims to analyze the improvement of the operational performance of Indonesia's Soekarno-Hatta Airport train through service quality which is mediated by train passenger loyalty and passenger satisfaction. The main problems in this study are the use of the same railway for longdistance train, airport train, and commuter Line train, the limited use of airport railway with four schedules, the headway which becomes 30 minutes since the number of travels becomes 82 trips, and the tariff being applied now is considered as burdening the passengers. The research method uses a quantitative analysis approach with the technique of Structural Equation Modeling-Lisrel. Data collection is done through observation and questionnaire distribution. The respondents are 306 passengers of trains heading for Soekarno-Hatta Airport. The benefit of this study for the domestic railway company is that by improving service quality, passenger loyalty and satisfaction, it will improve the operational performance of airport trains. The result of this research indicates the significant influence of service quality variable on passenger loyalty through passenger satisfaction, the significant influence of service quality variable on operational performance through passenger satisfaction and passenger loyalty as well as the significant influence of passenger satisfaction variable on operational performance through passenger loyalty.

\section{Introduction}

Airport trains in Jakarta City and surroundings operate outside the rush hours with four trips from Bekasi Station at 10.05, 11.10, 13.13, and 14.11 of Western Indonesia Time. The reverse trip from Soekarno-Hatta Airport starts at 07.50, 08.50, 10.50, and 11.50 of Western Indonesia Time. During Eid al-Fitr 2018, the Soekarno-Hatta Airport train recorded a surge in the number of passengers; usually, the daily average number of passengers was around 1,000 to 2,000, then its number has increased around twofold. Eid home-to-country transport starts to be seen through the increase of airport train passengers up to more than 5,000 people per day, indicating that people start to use airport train service as one of the transportation modes that support Eid transport in that year. Previously, citizens of Jakarta and its surroundings only had alternative transports of bus, taxi, or private vehicle to go to the airport and vice versa. Land transport faces terrible traffic jams due to imbalanced growth between the vehicle number and the length of road. Some airport train services complained by passengers among others are; (1) the insufficient operation of airport train which has been integrated with busway and Commuter Line, (2) the

* Corresponding author. Tel.: +628129204067

E-mail address: endri@mercubuana.ac.id (E. Endri)

(C) 2022 by the authors; licensee Growing Science, Canada. doi: $10.5267 /$ j.ijdns.2021.9.019 
constrained access to the airport, (3) the problems of providing City Check-In and dropping off passengers at the three terminals of Soekarno-Hatta Airport, (4) one service point shared by Commuter Line and airport train on the lines of BNI City Sudirman - Tanah Abang - Duri - Soekarno-Hatta Airport and vice versa, (5) the projected occupancy rate is $70 \%$ but the current real rate is $30 \%$, and (6) the problem of parking area for feeder transport in Bekasi Timur station.

In this study, the variables are operational performance as the most problematic performance with two mediating variables, namely passenger loyalty and passenger satisfaction, and service quality as the independent variable. Today, it can be said that the airport train is still limited in its integration and does not have the necessary national coordination for taking advantage of the intermodal transportation of the train to the airport (Chen \& Lin, 2016). Stubbs and Jegede (1998) also state that the integration plan of airport trains is not well-coordinated, so the use of intermodal transportation from and to the airport is not optimal. This integration has in the future resulted in a positive alternative on several aircraft routes and caused train travel to the airport to become part of air transportation services (Givoni, 2006; Givoni \& Banister, 2007). Thus, the integration will provide a better use of available air capacity than duplicating multiple routes and high-speed rail services. Based on research results of (Chiambaretto \& Decker, 2012), uncertainty regarding regulatory treatment may limit the spread and scope of airrail intermodal agreements.

Theoretically and based on previous studies, it can be described as follows. Some of the main problems in the management of train journey are schedule adjustment and train rescheduling which have ever been studied by (Jespersen-Groth et al., 2009); train operational performance studied by (Burdett \& Kozan, 2014; Espinosa-Aranda \& García-Ródenas, 2013; Fourie \& Zhuwaki, 2017). Train operational performance, according to (Patra, 2009), is explained through reliability, availability, maintainability, and safety as well as life cycle cost for train infrastructures and shows the model for effective infrastructure maintenance plan. Performance measurement based on the study by Stenström (2014) has been shown to improve organizational efficiency and effectiveness. However, the development and integration of performance measurement are also important (Riyanto et al., 2021)

Findings from the research by Banu (2018) in India conclude that improving service quality is one way to enhance the competitiveness of train services. Modified SERVQUAL instruments according to (Pahala et a., 2021; Cavana \& Corbett, 2007; Irfan et al., 2012) including some constructions of service quality such as empathy, assurance, physical evidence, punctuality, responsiveness, safety, and security are used to measure the passenger perception on the train service quality. Based on the result of research by Nuraizi et al. (2018), the ideal tariff is recommended after the service quality improvement made by the Soekarno-Hatta Airport train operator. To improve the service, the more holistic approach to control traffic is using the concept of a real-time traffic plan where the train driver will substantially improve the quality of train traffic control (Tschirner et al., 2014).

Findings from the research by Kumuthadevi (2013) reveal that the most important factors determining train passenger satisfaction are basic facilities, namely cleanliness, safety \& security, catering, health services, punctuality, behavior toward passengers. The research done by Partogi et al. (2017) in Indonesia analyzes the level of train passenger satisfaction, which is very important to be improved due to the unsatisfying service level. It is understood that customer loyalty is the main element that gives long-term profitability to companies (Chou et al., 2014).

A previous study in Indonesia by Wulansari (2016) on the model of transportation mode selection for the train to the airport includes: 1) Airport train and Bus, 2) Airport train and taxi, 3) Airport train and private vehicle (car). Subsequently, based on the sensitivity analysis it is known that the most sensitive to affect the probability of transportation mode selection is tariff (travel cost). For example, the airport train at New Yogyakarta International Airport was studied by Setiawan (2018) of which the result shows the ideal distance for the passengers who are willing to take the airport train to go to the city. According to Surbakti and Bombongan (2017) in their research want to know the characteristics of train and bus users from Medan to Kuala Namu Airport and how passengers will choose those two transportation modes. Various solutions have been considered including baggage handling, schedule coordination, and compensation for delays, but the question of price was not addressed (Chiambaretto et al., 2013). Factors in cooperation also affect the sensitivity of demand to price, horizontal differentiation between air and rail, and asymmetry in the investment costs of partnerships (Jiang et al., 2017). Another study in Shanghai, China according to Chen and Lin (2016), needs to look at the relationship between the Airport Authority, the Shanghai Railway Bureau, and airlines by encouraging the integration of air trains through the improvement of shared ticketing and code sharing, direct baggage transfers, provision of fast and convenient connections and expansion of the link service area air train.

The results of this study can be used as a reference to improve theoretical and empirical understanding of the competitive structure of the aviation industry and the value function for designing a competition strategy that has a sustainable orientation. Barrett (2004) pointed out the need for strategic planning for the aviation industry not only for domestic lowcost airlines (LCC) or full-service operators. The research objective is to analyze the improvement of the operational performance of Indonesia's Soekarno-Hatta Airport train through service quality which is mediated by train passenger loyalty and passenger satisfaction. To prove the research objectives empirically, the hypotheses to be tested are as follows: 
H1: Service Quality $(X)$ has a direct effect on Passenger Satisfaction $\left(Y_{l}\right)$.

$\mathbf{H}_{2}$ : Service Quality $(X)$ has a direct effect on Passenger Loyalty $\left(Y_{l}\right)$.

$\mathbf{H}_{3}$ : Passenger Satisfaction $(Y)$ has a direct effect on Passenger Loyalty $\left(Y_{2}\right)$.

$\mathbf{H}_{4}$ : Service Quality $(X)$ has a direct effect on Operational Performance $(Z)$.

$\mathbf{H}_{5}$ : Passenger Loyalty $\left(Y_{l}\right)$ has a direct effect on Operational Performance (Z).

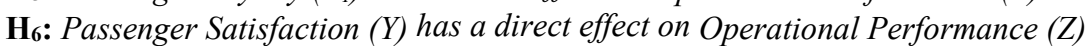

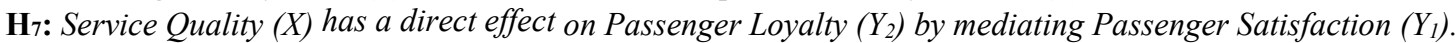

H8: Service Quality $(X)$ has a direct effect on Operational Performance (Z) by mediating Passenger Satisfaction $\left(Y_{I}\right)$ and Passenger Loyalty $\left(Y_{2}\right)$.

H9: Passenger Satisfaction $\left(Y_{l}\right)$ has a direct effect on Operational Performance (Z) by mediating Passenger Loyalty $\left(Y_{2}\right)$.

We propose service quality as an analytical tool that can improve the operational performance mediated by passenger satisfaction and passenger loyalty. Figure 1 describes the conceptual framework of this research with nine research hypotheses based on the research constellation, both direct and indirect.

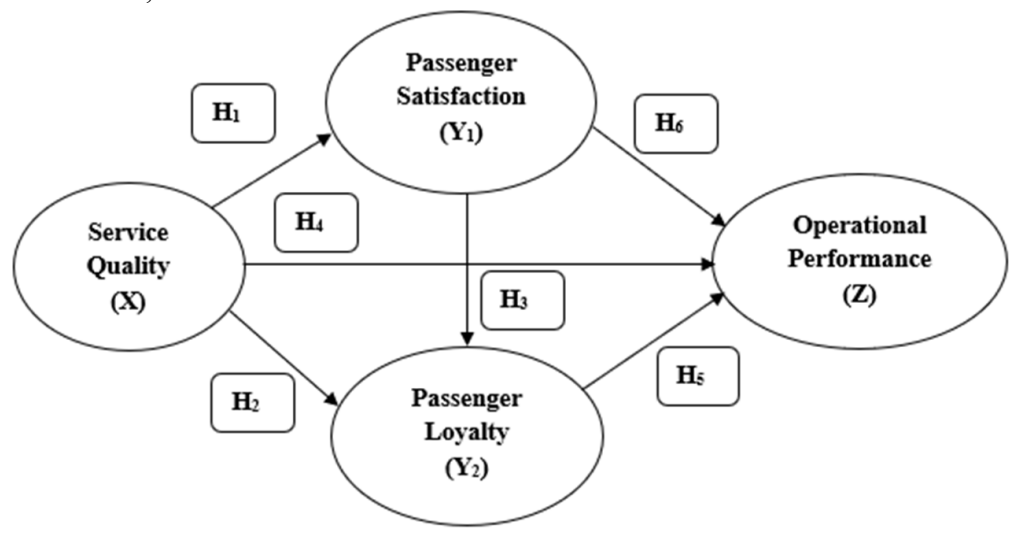

Fig. 1. Research Variable Constellation Model

\section{Research Method}

There are four latent variables in this research, namely Service Quality $(\mathrm{X})$ as an independent variable, Passenger Satisfaction $\left(\mathrm{Y}_{1}\right)$ and Passenger Loyalty $\left(\mathrm{Y}_{2}\right)$ as intervening variables, and Operational Performance $(\mathrm{Z})$ as the dependent variable. Each of the latent variables is measured by some observed variables/indicators. The research uses a quantitative method with the model of Structural Equation Modeling (SEM) Lisrel. According to (Hair et al., 2014), data collection uses a sampling technique and is carried out through observation unit groups of Proportionate Stratified Random Sampling with Slovin formula. The respondents are 306 train passengers going to Soekarno-Hatta Airport out of 1,300 passengers as the population. The respondents who fill in the questionnaires depart from four stations, namely Manggarai, Sudirman Baru, or BNI City, Batu Ceper leaving for Soekarno-Hatta Airport. SEM for quantitative analysis is much used by previous researchers to test the conceptual framework. Lisrel Program 8.7.1 shows the measurement of structural problems and is used to test the hypothesis model. The research steps using such SEM-Lisrel includes; (1) descriptive analysis, as the description of respondent's response data, (2) initial evaluation, namely Confirmatory Factor Analysis; (3) validity and reliability test of measurement model; (4) testing of full structural model (Standardized); (5) evaluation on the index of fit model structural; (6) testing of full model Structural (T values); (7) estimated structural model of the inter-relations of latent variables through path coefficient test; and (8) hypothetical test.

\section{Results and Discussion}

\subsection{Result of Full Structural Model Testing}

The result of the structural equation test is presented in Fig. 2. The test of the full model of SEM is carried out in two kinds of testing, namely model fitness and hypothetical test of the model. The test of the full model of SEM is used to see the model worthiness or model fitness. The evaluation of good fitness of the Structural Equation Model is done by comparing the recommended values of the fitness index. The result of model fitness testing overall uses the $X^{2}$ (chi-square) test which obtains the value of 328.26 with a p-value of 0.000 and RMSEA of 0.072 . Referring to the value of RMSEA, the model has been fit as well as with most of the other GOF indexes that have fulfilled the fitness criteria so that it can continue to the next step of the analysis. 


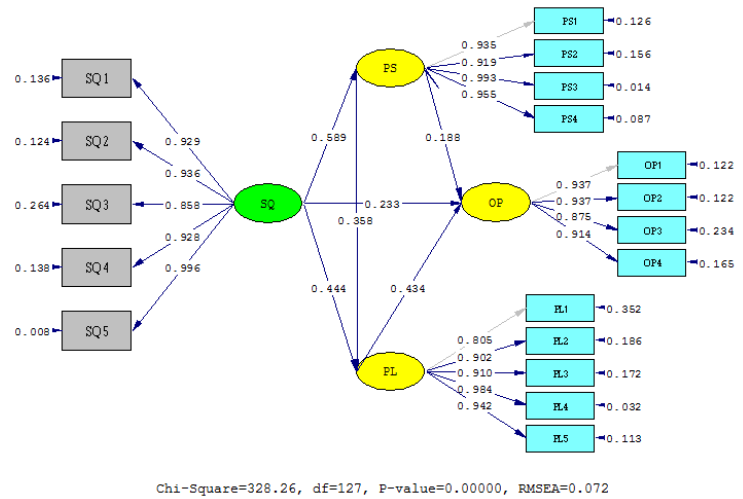

Fig. 2. Result of full Structural model testing (Standardized)

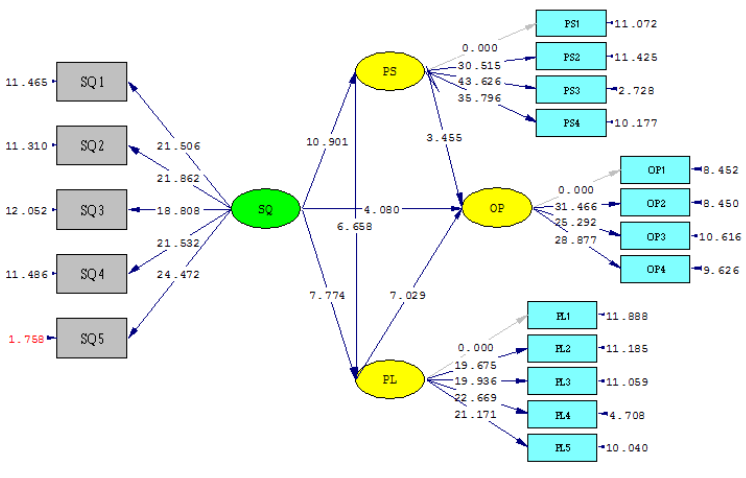

Chi-Square $=328.26, \mathrm{df}=127, \mathrm{P}$-value $=0.00000, \mathrm{RMSEA}=0.072$

Fig. 3. Result of full Structural model (T values)

After the model fitness test, the next step is to research hypothetical testing through a structural model (Fig. 3). From the recapitulation stated, it can be known that in the first substructure, the Service Quality variable gives 34.7\% influence to PS, whereas the rest of $65.3 \%$ is given by other variables which are not studied. In the second substructure, service quality and passenger satisfaction variables give $51.3 \%$ influence to passenger loyalty whereas the rest of $48.7 \%$ is given by other variables which are not studied. In the third substructure, service quality, passenger satisfaction, and passenger loyalty variables give $56.3 \%$ influence to operational performance whereas the rest of $43.7 \%$ is given by other variables which are not studied.

\subsection{Hypothetical Testing}

Based on the path coefficient of service quality to passenger satisfaction is as big as 0.589 in a positive direction. it means the better the service quality the higher the Passenger Satisfaction will be. Based on the test result it can be concluded that hypothesis 1 is accepted, meaning that service quality significantly affects passenger satisfaction; the better the service quality the higher the passenger satisfaction will be. This study supports the studies done by some researchers in Indonesia such as (Ningsih $\&$ Suryalena, 2017), that service quality comprising tangibility, reliability, responsiveness, assurance, empathy simultaneously show the significant result on the satisfaction of train passengers of Padang Pariaman in West Sumatera and Surabaya. Whereas other researches by (Chou et al., 2014; Foroutan et al., 2016; Tamaruddin et al., 2020; Ibrahim et al., 2019; Ramseook-Munhurrun et al., 2010). Thus, the result of this research is in line with theoretical studies and the result of previous related research. It means that service quality affects passenger satisfaction.

\subsection{Service Quality affects Passenger Loyalty}

From the path coefficient of service quality toward the passenger, loyalty is 0.44 with a positive direction. It means that the better service quality the higher passenger loyalty will be. Based on the test result it can be concluded that hypothesis 1 is accepted, meaning that service quality significantly affects passenger loyalty, the better the service quality the higher passenger loyalty will be. This study supports the research done by some researchers like (Segoro, 2013) which has a result showing that service quality directly and positively affects customer loyalty. Research by Chou and Kim (2009) uses service quality and loyalty variables as important factors which affect the long-term operation, growth, and the advantage of a service-oriented transportation system. Thus, the result of this study is in line with theoretical studies and the result of previous related studies, although some research reveals that service quality does not have a significant influence on customer loyalty variable. It means that service quality affects passenger loyalty.

\subsection{Passenger satisfaction affects Passenger Loyalty}

The path coefficient of Passenger Satisfaction toward Passenger Loyalty is 0.358 with a positive direction. It means the higher Passenger Satisfaction the higher Passenger Loyalty will be. Based on the test result it can be concluded that Hypothesis 1 is accepted, meaning that Passenger Satisfaction significantly affects Passenger Loyalty, the higher Passenger Satisfaction the higher Passenger Loyalty will be. This study supports the result of research by Foroutan et al. (2016) showing that the result of research on Zendegi traina in Iran shows that passenger satisfaction has a significant relation with passenger loyalty. The same test in Iran finds a positive relationship between satisfaction and passenger loyalty (Esmaeili et al., 2013). It means passenger satisfaction affects passenger loyalty. According to Yuan et al. (2021), passenger satisfaction and impact on loyalty and user complaints indicate that several groups of passengers share common interests in ticketing services, reliability, accessibility, and convenience. While some striking differences in perceptions are identified in personalized services, information services, and connectivity. 


\subsection{Service Quality affects Operational Performance}

The path coefficient of service quality toward operational performance is 0.233 with a positive direction. It means that the better service quality the better operational performance will be. Based on the test result it can be concluded that hypothesis 1 is accepted, meaning that service quality significantly affects operational performance; the better the Service quality the better operational performance will be. Previous research on the Soekarno-Hatta Airport train has been done by Nuraizi et al. (2018) discussing the recommended ideal tariff after improving the priority quality or the service provided by the operator. Thus, the result of this study is in line with theoretical studies and the result of previous related studies. It means that service quality affects operational performance.

\subsection{Passenger Satisfaction affects Operational Performance}

The path coefficient of passenger satisfaction toward service quality is 0.188 with a positive direction. It means that the higher the passenger satisfaction the higher the operational performance will be. Based on the test result it can be concluded that hypothesis 1 is accepted, meaning that passenger satisfaction significantly affects operational performance; the higher the passenger satisfaction the higher the operational performance will be. Aydin et al. (2015) provide a customer satisfaction framework to measure the performance of transit train lines in Istanbul, Turki. Thus, the result of this study is in line with theoretical studies and the result of previous related studies. It means that passenger satisfaction affects operational performance.

\subsection{Passenger Loyalty affects Operational Performance}

From the path coefficient of passenger loyalty toward service, quality is 0.434 with a positive direction. It means the higher the passenger loyalty the higher the operational performance will be. Based on the test result it can be concluded that hypothesis 1 is accepted, meaning that passenger loyalty significantly affects passenger loyalty; the higher the passenger satisfaction the higher the operational performance will be. This study supports the result of research done by some researchers like Chou and Yeh (2013) who add in their research that the increase of evaluation indicator will be able to enhance passenger loyalty and improve operational performance in train service. Thus, the result of this study is in line with theoretical studies and the result of previous related studies. It means that passenger loyalty affects operational performance,

\subsection{Mediation Testing}

The seventh hypothesis tested is the indirect influence of service quality on passenger loyalty through passenger satisfaction. In the result table of estimated influence size among research variables (mediation), it can be known that the path coefficient of the direct influence of service quality on passenger loyalty is 0.444 and the indirect influence through passenger satisfaction (indirect effect) is 0.211 so that the total effect of service quality on passenger loyalty through passenger satisfaction both directly and indirectly (total effect) is obtained 0.655 . From this result, it can be known that the total indirect influence of service quality on passenger loyalty through passenger satisfaction is 0.655 bigger than its direct influence as big as 0.211 . This indicates that the passenger satisfaction variable has a positive contribution in mediating the relation between service quality and passenger loyalty.

\subsection{Indirect Influence of Service Quality on Passenger Loyalty through Passenger Satisfaction}

The obtained value of $t_{\text {he }}$-statistic is 0.211 bigger than $t_{\text {he }}$-table $(1.96)$. Since the value of $t_{\text {-statistic }}(0.211)$ is bigger than 1.96 , then in the error rate of $5 \%$ (two tails) it is decided to accept $\mathrm{H}_{1}$ and reject $\mathrm{H}_{0}$ so that the seventh hypothesis is accepted. Thus, it can be concluded that there is an indirect significant influence of service quality variable on passenger loyalty through passenger satisfaction. The results of research by Foroutan et al. (2016) in Iran and according to Chou et al. (2014) in Taiwan; explain that train service quality has a significant relation with passenger satisfaction, and customer loyalty. Passenger satisfaction has a significant relation with passenger loyalty. Thus, the result of this study is in line with theoretical studies and the result of previous related studies. It means that there is an indirect significant influence of service quality variable on passenger loyalty through passenger satisfaction.

3.10. Indirect influence of Service Quality on Operational Performance through Passenger Satisfaction and Passenger Loyalty

The obtained value of $t_{\text {he }}$-statistic is 8.051 bigger than the value of $t_{\text {he }}$-table $(1.96)$. Since the value of $t_{\text {-statistic }}(8.051)>1.96$, at an error rate of 5\% (two-tail) it is decided to accept $\mathrm{H}_{1}$ and reject $\mathrm{H}_{0}$ so that the eighth hypothesis is accepted. Thus, it can be concluded that there is an indirect significant influence of service quality variable on operational performance through passenger satisfaction and passenger loyalty. This study also supports the research done by Kao and Xu (2017) in Taiwan explaining that the improvement of performance and service quality will give higher satisfaction, enhance loyalty, and passenger's willingness to keep using the train. Thus, the result of this study is in line with theoretical studies and the result of previous related studies. It means that there is an indirect significant influence of service quality variable on operational performance through passenger satisfaction and passenger loyalty. 


\subsection{The indirect influence of Passenger Satisfaction on Operational Performance through Passenger Loyalty}

The obtained value of $t_{\text {-statistic }}$ is 5.047 bigger than the value of $t_{\text {-Table }}(1.96)$. Since the value of $t_{\text {-statistic }}(5.047)>1.96$, then at an error rate of $5 \%$ (two-tail), it is decided to accept $\mathrm{H}_{1}$ and reject $\mathrm{H}_{0}$ so that the ninth hypothesis is accepted. Thus, it can be concluded that there is an indirect significant influence of passenger satisfaction variable on operational performance through passenger loyalty. Research using several indicators of train service performance is done by some researchers (Permana et al., 2021; Chou et al., 2014; Chou \& Yeh, 2013; Eprilianto, 2013). Thus, the result of this study is in line with theoretical studies and the result of previous related studies. It means that there is a significant influence of passenger satisfaction variable on operational performance through passenger loyalty. The contribution and novelty that will be resulted from this study is that this study can give an explanation to people about the operational performance of the airport train company related to service quality, passenger loyalty, so it can be hoped to improve the service and enhance passenger satisfaction.

\section{Conclusion}

The results of this research can be explained from the dimension of airport train service quality, access for train passengers facilitating to continue their trip to the airport without going out of railway station, and the schedule of departure and arrival available and attached at the railway station or in publication media. Officers will give information if there is an obstruction of the travel clearly and communicatively. Some improvements are needed; in terms of train schedule, it should be integrated with airlines, railway management needs to be more responsive to all complaints from train passengers. In terms of passenger satisfaction, the design of a passenger seat with a backrest like an aircraft seat that can be laid down gives comfort to passengers during travel; providing a rack for luggage near the entrance gives convenience to passengers. Meanwhile, ticket prices are still not fully acceptable to the public. In terms of loyalty, passengers get more certainty of travel time by train to the airport than other transports so that they take Airport train into account as the main choice. Ergonomic and comfortable seats also determine passenger loyalty. In the operational performance, the operational schedule of airport train arrival and departure set up by the railway management can avoid rush hours so that it does not obstruct the schedule of regular trains, and the travel time from BNI City station to the airport targeted to be 30 minutes is very realistic. To improve the service performance, the use of rail for airport trains should be aligned with the rail for the commuter train so the travel time to the airport will not become longer. It also needs to pay attention to the punctuality of train arrival and departure from and to the airport.

\section{References}

Aydin, N., Celik, E., \& Gumus, A. T. (2015). A hierarchical customer satisfaction framework for evaluating rail transit systems of Istanbul. Transportation Research Part A: Policy and Practice, 77, 61-81. https://doi.org/10.1016/j.tra.2015.03.029

Banu, I. P. (2018). Determinants of Passenger Satisfaction on Service Quality in Southern Railways with Reference to Salem Division. International Journal of EngineeringTechnology Science and Research, 5(1), 389.

Barrett, S. (2004). How do the demands for airport services differ between full-service carriers and low-cost carriers?'. Journal of Air Transport Management, 10, 33-39.

Burdett, R. L., \& Kozan, E. (2014). Performance profiling for predictive train schedules. Journal of Rail Transport Planning \& Management. Journal of Rail Transport Planning \& Management, 4(4), 98-114. https://doi.org/10.1016/j.jrtpm.2014.11.002

Cavana, R. Y., \& Corbett, L. M. (2007). Developing zones of tolerance for managing passenger rail service quality. International Journal of Quality \& Reliability Management, 24(1), 7-31. https://doi.org/10.1108/02656710710720303

Chen, X., \& Lin, L. (2016). The integration of air and rail technologies: Shanghai's Hongqiao integrated transport hub. Journal of Urban Technology, 23(2), 23-46. https://doi.org/10.1080/10630732.2015.1102418

Chiambaretto, P., Baudelaire, C., \& Lavril, T. (2013). Measuring the willingness-to-pay of air-rail intermodal passengers. Journal of Air Transport Management, 26, 50-54. https://doi.org/10.1016/j.jairtraman.2012.10.003

Chiambaretto, P., \& Decker, C. (2012). Air-rail intermodal agreements: Balancing the competition and environmental effects. Journal of Air Transport Management, 23, 36-40. https://doi.org/10.1016/j.jairtraman.2012.01.012

Chou, J. S., \& Kim, C. (2009). A structural equation analysis of the QSL relationship with passenger riding experience on high-speed rail: An empirical study of Taiwan and Korea. Expert Systems with Applications, 36(3), 6945-6955.

Chou, J. S., \& Yeh, C. P. (2013). Influential constructs, mediating effects, and moderating effects on operations performance of high-speed rail from a passenger perspective. Transport Policy, 30, $207-219$. https://doi.org/10.1016/j.tranpol.2013.09.014

Chou, Lu, \& Chang. (2014). Effects of service quality and customer satisfaction on customer loyalty in high-speed rail services in Taiwan. Transportmetrica A: Transport Science, $10(10)$, $917-945$. https://doi.org/https://doi.org/10.1080/23249935.2014.915247

Eprilianto, D. F. (2013). Service Performance Indicators As An Effort To Improve Quality Of Public Services at Yogyakarta Lempuyangan Station. Jurnal Natapraja, 1(1), 60-74.

Esmaeili, A. A., Manesh, B. A., \& Golshan, E. (2013). Service quality, customer satisfaction, and customer loyalty in RAJA rail transportation company. International Research Journal of Applied and Basic Sciences, 4(12), 4248-4253. 
Espinosa-Aranda, J. L., \& García-Ródenas, R. (2013). A demand-based weighted train delay approach for rescheduling railway networks in real-time. Journal of Rail Transport Planning \& Management, 3(1-2), 1-13. https://doi.org/10.1016/j.jrtpm.2013.10.001

Foroutan, S., Roknabadi, A. D., Nayebzadeh, S., Meybodi, L. S., \& Eghbali, A. (2016). Investigating the Impact of Service Quality of "Zendegi" Train on the Passengers' Loyalty and Satisfaction. International Journal of Humanities and Cultural Studies (IJHCS), 1(1), 1499-1515.

Fourie, C. J., \& Zhuwaki, N. T. (2017). A modeling framework for railway infrastructure reliability analysis. South African Journal of Industrial Engineering, 28(4). https://doi.org/10.7166/28-4-1763.

Givoni, M. (2006). Development and impact of the modern high-speed train: a review. Transport Reviews, 26(5). https://doi.org/10.1080/01441640600589319

Givoni, M., \& Banister, D. (2007). Role of the railways in the future of air transport. Transportation Planning and Technology, 30(1), 95-112. https://doi.org/10.1080/03081060701208100

Hair, J. F., Black, W. C., Babin, B. J., \& Anderson, R. E. (2014). Multivariate Data Analysis (7th eds.). Pearson Education Limited.

Ibrahim, Borhan, Zakaria, \& Zainal. (2019). Effectiveness of Commuter Rail Service Toward Passenger's Satisfaction: a Case Study from Kuala Lumpur, Malaysia. International Journal of Engineering and Technology, 8(1.2), 50-55. https://doi.org/10.14419/ijet.v8i1.2.24871

Irfan, S. M., Kee, D. M. H., \& Shahbaz, S. (2012). Service quality and rail transport in Pakistan: A passenger perspective. World Applied Sciences Journal, 18(3), 361-369.

Jespersen-Groth, J., Potthoff, D., Clausen, J., Huisman, D., Kroon, L., Maróti, G., \& Nielsen, M. N. (2009). Disruption management in passenger railway transportation. In Robust and online large-scale optimization. In Robust and online large-scale optimization.

Jiang, C., D'Alfonso, T., \& Wan, Y. (2017). Air-rail cooperation: Partnership level, market structure, and welfare implications. Transportation Research Part B: Methodological, 104, 461-482. https://doi.org/10.1016/j.trb.2017.01.006

Kao, C. K., \& Xu, L. (2017). Study on the Performance Measurement of Taiwan Railway Service Quality through Grey Relational Analysis. NternationalReview of Management and BusinessResearch, 6(2), 655-688.

Kumuthadevi, K. (2013). Service Quality of South Indian Railway- Determinants of Passenger Satisfaction in Trains. International Journal of Business and Management, 2(2), 49-54

Ningsih, Y., \& Suryalena. (2017). Effect of Service Quality on Consumer Satisfaction at PT Kereta Api Indonesia (Persero) Regional Division II West Sumatra Padang Pariaman. Online Student Journal (JOM) in Social and Political Sciences, $5(1), 1-5$.

Nuraizi, A., Saksono, I. A., Hidayat, M., Nasution, N. A., \& Saksono, A. K. (2018). Analyzing The Customersâ€ ${ }^{\mathrm{TM}}$ Ability to Pay And Willingness To Pay For Soekarno Hatta Airport Railway Services (From BNI City Station). Advances in Transportation and Logistics Research, 1(1), 150-165.

Pahala, Y., Widodo, S., Kadarwati., Azhari, M., Muliyati., Lestari, N.I., Madjid, S.A., Sidjabat, S., Limakrisna, N., \& Endri, E. (2021). The effects of service operation engineering and green marketing on consumer buying interest. Uncertain Supply Chain Management, 9(3), 603-608. https://doi: 10.5267/j.uscm.2021.5.011

Partogi, Y., Dewangga, M. I. V., \& Hutauruk, P. S. (2017). The Analysis of Customers' Satisfaction Towards Commuter Line Train Service a Case Study at Bekasi Station, Bekasi - Jakarta Kota Route. Advances in Engineering Research (AER), Volume 147 Conference on Global Research on Sustainable Transport (GROST 2017), 629-641. https://doi.org/10.2991/grost-17.2018.54

Patra, A. P. (2009). Maintenance decision support models for railway infrastructure using RAMS \& LCC analyses. The Luleå University of Technology.

Permana, A., Aima, M.H., Ariyanto, E., Nurmahdi, A., Sutawidjaya, A.H., \& Endri, E. (2021). The effect of compensation and career development on lecturer job satisfaction. Accounting, 7(6), 1287-1292. doi: 10.5267/j.ac.2021.4.011

Ramseook-Munhurrun, P., Lukea-Bhiwajee, S. D., \& Naidoo, P. (2010). Service quality in the public service. International journal of management and marketing research. International Journal of Management and Marketing Research, 3(1), 3750.

Riyanto, S., Endri E., \& Herlisha, N. (2021). Effect of work motivation and job satisfaction on employee performance: Mediating role of employee engagement. Problems and Perspectives in Management, 19(3), 162-174. doi:10.21511/ppm.19(3).2021.14

Segoro, W. (2013). The influence of perceived service quality, mooring factor, and relationship quality on customer satisfaction and loyalty. Procedia-Social and Behavioral Sciences, 81, 306-310.

Setiawan, D. (2018). Analysis of the Preference for the Use of Airport Railway Modes Towards New Yogyakarta International Airport. SEMESTA TEKNIKA, 21(1), 43-52.

Stenström, C. (2014). Operation and maintenance performance of rail infrastructure: Model and Methods. The Luleå University of Technology.

Stubbs, J., \& Jegede, F. (1998). The integration of rail and air transport in Britain. Journal of Transport Geography, 6, 5367. https://doi.org/10.1016/S0966-6923(97)00039-2

Surbakti, M., \& Bombongan, C. (2017). Characteristic of Modal Choice Preference between Bus and Train from Medan to Kuala Namu Airport. IOP Conference Series: Materials Science and Engineering, 180(1).

Tamaruddin., Firdaus, A., \& Endri, E. (2020). Customer Satisfaction Mediates the Effect of Self Service Technology on 
Customer Loyalty in Islamic Bank E-Banking Services in Indonesia. ILTIZAM Journal of Shariah Economics Research, 4(2), 1-15. DOI: https://doi.org/10.30631/iltizam.v4i2.596

Tschirner, S., Sandblad, B., \& Andersson, A. W. (2014). Solutions to the problem of inconsistent plans in railway traffic operation. Journal of Rail Transport Planning \& Management, 4(4), 87-97. https://doi.org/10.1016/j.jrtpm.2014.10.002

Wulansari, D. N. (2016). Analysis of the Selection of Passenger Transportation to the Airport (Case Study: Soekarno-Hatta International Airport). Journal of Civil Engineering Studies, 1(2), 90-100.

Yuan, Y., Yang, M., Feng, T., Rasouli, S., Ruan, X., Wang, X., \& Li, Y. (2021). Analyzing heterogeneity in passenger satisfaction, loyalty, and complaints with air-rail integrated services. Transportation Research Part D: Transport and Environment, 97, 102950. https://doi.org/10.1016/j.trd.2021.102950

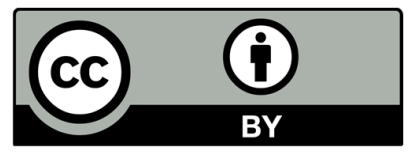

(C) 2022 by the authors; licensee Growing Science, Canada. This is an open access article distributed under the terms and conditions of the Creative Commons Attribution (CC-BY) license (http://creativecommons.org/licenses/by/4.0/). 